原発性空腸悪性リンパ腫の 1 例

\author{
小野田市立病院外科 \\ 西山 利弘福田 重年 山下 勝之

\section{A CASE OF MALIGNANT LYMPHOMA OF THE JEJUNUM}

\section{Toshihiro NISHIYAMA, Shigetoshi FUKUDA, Katsuyuki YAMASHITA} \\ Department of Surgery, Onoda City Hospital
}

索引用語：原発性小腸悪性リンパ腫

はじめに

原発性小腸悪性リンパ腫は，比較的をれな疾患であ る. 最近われわれは, 原発性空腸悪性リンパ腫の 1 例 を経験し，あわせて本邦報告例を集計したので，若干 の文献的考察を加えて報告する。

\section{症例}

症例：62歳, 男性.

主訴：腹部膨満, 呕叶.

既往歴：21歳の時に虫垂切除術.

現病歴：昭和58年 9 月中旬より胃潰瘍の治療を受け ていたが,そのころより腹部膨満感があった。 その後, 時々呕吐を伴なうようになり当院内科受診, 治療を受 けるる次第に増悪するため, 昭和 59 年 3 月当科紹介入 院となる。

\section{表 1 入院時血液検査成績}

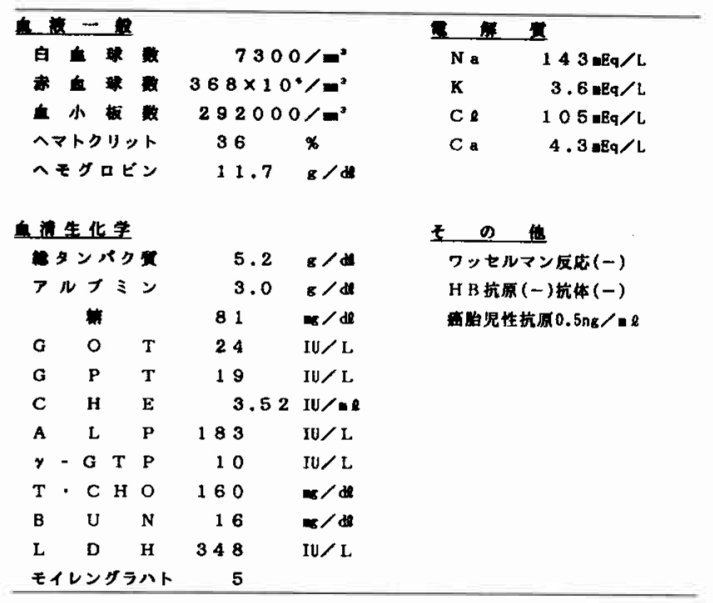

$<1985$ 年 9 月 11 日受理 > 別刷請求先：西山 利弘 干756 小野田市東高泊1863-1 小野田市立病院外 科
入院時現症 : 左上腹部に軽度圧痛を認める以外特に 異常所見なし.

入院時血液検查：軽度の低蛋白血症を認める以外， 諸検査成績はほぼ正常範囲内であった（表 1 ).

小腸透視：Treitz 靯帯より約 $90 \mathrm{~cm}$ 肛門側の空腸に いわゆる overhanging edge ${ }^{1)}$ と潰場を伴なら狭窄像, ならびに口側空腸の拡張を認めた（図 1).

小腸内視鏡 (SIF-B，オリンパス社製)：狭窄部より 口側粘膜の発赤ならびに Kerckring 解璧の消失がみ られたが，その肛門側に腫瘍を確認するまでには至ら ず, 生検でも確定診は得られなかった.

上腸間膜動脈造影：腫瘍血管が乏しい以外に異常所 見を見い出しえなかった（図2）。

開腹所見：空腸腫煌の診断の下に昭和59年 3 月 26 日 開腹した. 腹水は認められず, Treitz 靯帯より $90 \mathrm{~cm}$ 肛

因 1 小腸透視

Treitz 靬帯より約 $90 \mathrm{~cm}$ 肛門側空腸の狭窄像と，そ の口側の拡張が認められた。

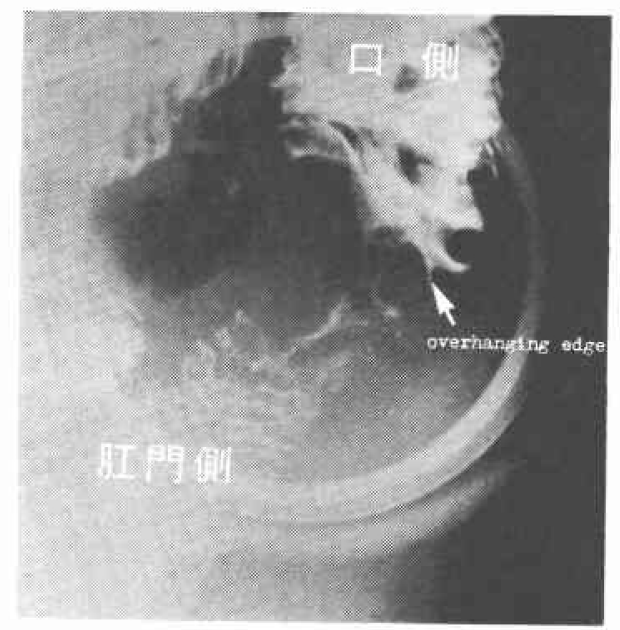


困 2 上腸間膜動脈造影

腫場部は (矢印) hypovascularity を呈していた。

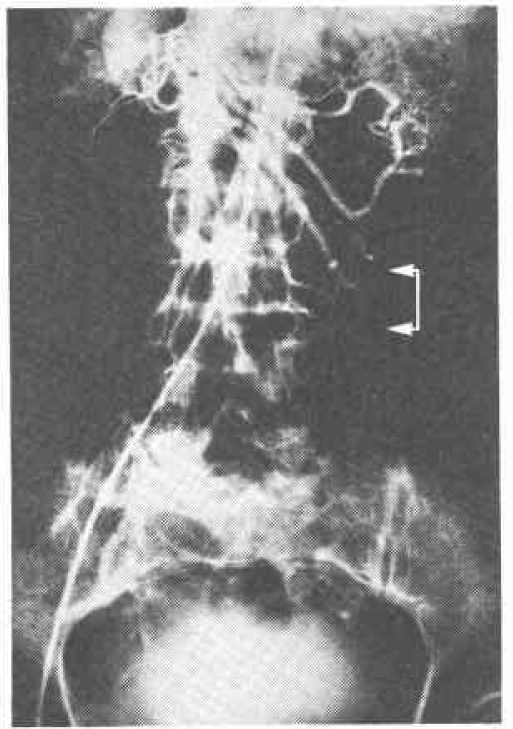

門側空腸に, 約 $3 \times 4 \mathrm{~cm}$, 弾性硬の腫瘍を認め, 腹腔内 に転移を思わせる所見は認められなかったが，悪性腫 癔を疑い，小腸広範囲切除術を施行した。

切除標本：腫瘍は全周性に肥厚狭窄像を呈してお り，その中心は浅い潰瘍を伴なっていたはた一部浆 膜面への浸潤を認めた（図 3). 森ら $\left.{ }^{2}\right)$ 肉眼分類に準 ずると絞縮型に相当すると思われた，切除標本の microangiographyでは, 畽瘍部は avascular を呈して いた（図 4 ).

病理組織所見：小腸粘膜から浆膜にかけて腫煌細胞 が diffuse に増生, 結節を形成し, LSG 分類による, い

\section{図 3 切除標本}

腫瘍は全周性に肥厚狭窄像を呈して放り，その中心 は浅い潰湯を伴なっていた。

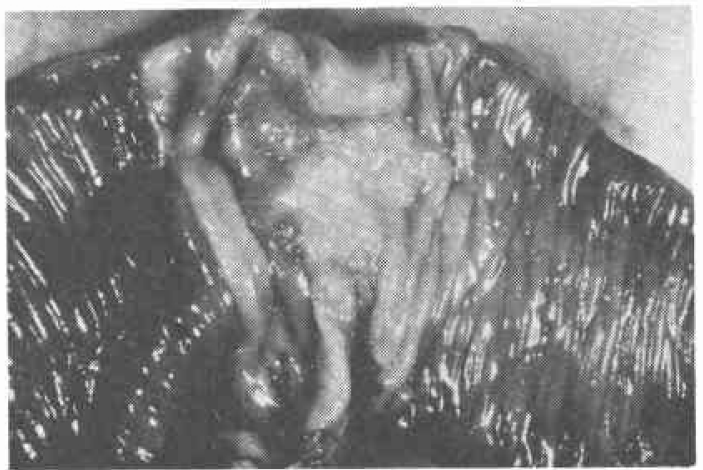

图 4 切除標本の microangiography 尰瘍部（矢印）は avascularであった。

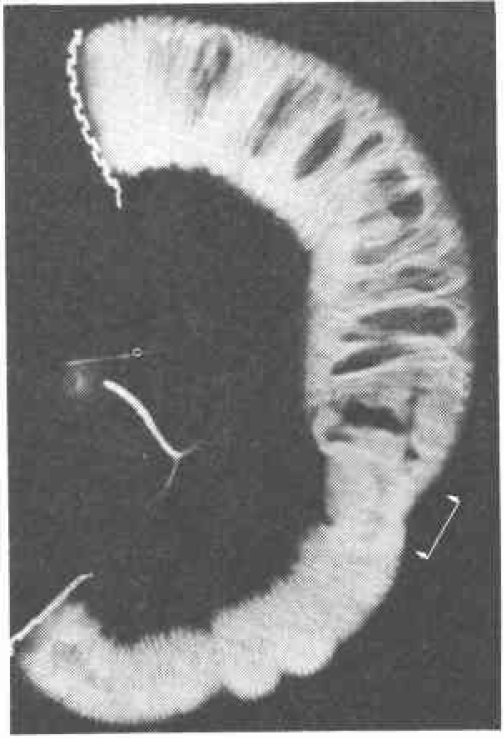

図 5 病理組織像

LSG 分類による diffuse intermadiate type の悪性 リンパ畽であった。

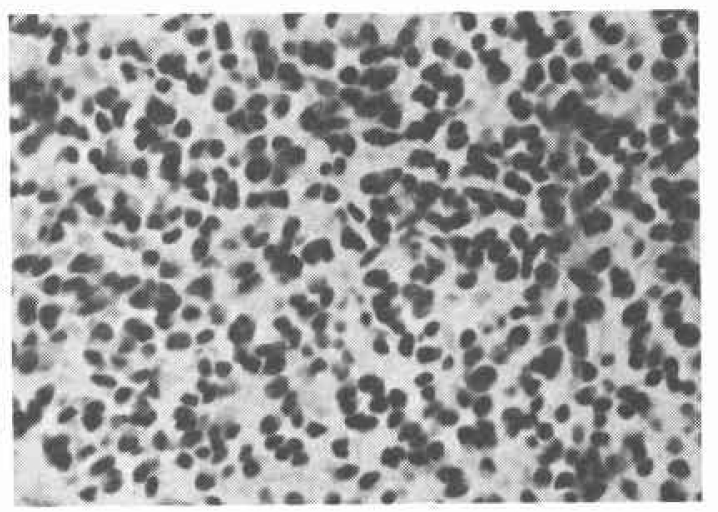

わゆる diffuse intermediate type ${ }^{3)}$ 悪性リンパ腫で あった（図 5 ).

転㷌：術後 1 年 3 カ月目までの現在まで, Vincristine, Cyclophosphamide, Pepleomycin, Prednisolone の 4 剂併用による化学療法を合計 4 クール行い, 特に 異常なく経過中である.

\section{考察}

八尾らは4)，1970年から79年本での10年間に本邦で 報告された空・回腸腫瘍の集計を行っている。その中 で悪性リンパ腫は259例であった。今回, われわれは, 
1980年から83年までの 4 年間で67例を集計しえた。こ れに自験例を加えた68例と，八尾らの259例とを合わせ た327例中, 記録のあきらかなものについて臨床的考察 を加忩てみた。

性別年代別頻度：男性205例, 女性69例の計274例で, 男女比漂注 3 対 1 と男性に多かった。年代別では，10 歳未満から80歳台まで幅広く分布していたが，50歳台 が59例と最多で，40から60歳台までで全体の60\%を占 めていた（表 2 ).

腫瘍の数と大きさ：腫瘍の数は193例に記載されて 括り，単発例は 139 例， $72 \%$, 多発例は 54 例, $28 \%$ で, 小腸癌や平滑筇肉腫よりも多発する傾向にある4). 腫 瘍の大きさが記載されていたものは129例であった。 5 10cm のものが 48 例, $37.2 \%$ と最も多く, 次いで 2.5 ～ $\mathrm{cm} 44$ 例， $34.1 \%$ あった(表 3). 八尾らは4), 2.6 10cm のすのが全体の $66.4 \%$ 占め, $5 \mathrm{~cm}$ 以下は 全体の $40.4 \%, 10 \mathrm{~cm}$ を越すものは $25.2 \%$ あっった 述べている。

腫瘍の存在部位：集計総数は空腸52例, 回腸122例 で, 回腸に多かった。存在部位別では, Bauhin弁より

表 2 性別年代別頻度

性 別频 度

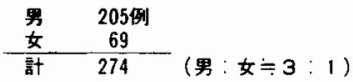

年代别頻度

\begin{tabular}{crr}
\multicolumn{1}{c}{ 年代 } & 例数 & \multicolumn{1}{c}{$\%$} \\
\hline $0 \sim 9$ & 14 & $(5.0)$ \\
$10 \sim 19$ & 9 & $(3.2)$ \\
$20 \sim 29$ & 15 & $(5.4)$ \\
$30 \sim 39$ & 29 & $(10.4)$ \\
$40 \sim 49$ & 52 & $(18.7)$ \\
$50 \sim 59$ & 59 & $(21.2)$ \\
$60 \sim 69$ & 58 & $(20.9)$ \\
$70 \sim 79$ & 36 & $(12.9)$ \\
$80 \sim 89$ & 6 & $(2.2)$ \\
\hline & 278 &
\end{tabular}

表 3 腫煌の数と大ささ

腫 瘍の数

\begin{tabular}{rrr} 
& 例数 & $\%$ \\
\hline 単発例 & 139 & $(72.0)$ \\
多発例 & 54 & $(28.0)$ \\
\hline & 193 &
\end{tabular}

腫瘍の大きさ

\begin{tabular}{|c|c|c|c|}
\hline \multicolumn{2}{|c|}{ 保 } & 例数 & $\%$ \\
\hline $2.5 c$ & ก以下 & 9 & $(7.0)$ \\
\hline 5 & " & 44 & $(34.1)$ \\
\hline 10 & $"$ & 48 & $(37.2)$ \\
\hline 15 & " & 18 & $(13.9)$ \\
\hline 20 & $" 1$ & 5 & $(3.9)$ \\
\hline $20<$ & & 5 & (3.9) \\
\hline
\end{tabular}

$20 \mathrm{~cm}$ 以内に 89 例, $73 \%$ と多発していた。一方小腸全体 でみると, Bauhin 弁より 40cm 以内が174例中101例, $58 \%$ と多く発生していた（図 6)，諸家の報告をみて も ${ }^{4)-6)}$, 回腸, 特に終末部に多いとされている。これは 本疾患が小腸粘膜の Payer 氏板から発生すると考克 られて扣り，終末回腸で Payer 氏板がよく発達してい ることに起因すると思われる。

臨床症状：253例より記載されたすべての症状を集 計した。腹痛149例， $58.9 \%$, 腹部腫瘤73例， $28.9 \%$, 呕吐 41 例， $16.2 \%$ ，腸重積37例，14.6\%，イレウス及 び消化管出血34例, $13.4 \%$, 以下表に示すごとくであっ た (表 4 ).

これら諸症状は悪性リンパ腫に特異なるのとはい兄 ず，臨床症状のみより本疾患を疑うことは困難である と思われた。

本疾患の小腸透視上の所見として, 田中は1), (1)腸管 長軸方向の発育を示す病変, (2)正常腸管幅前後の全周 性病変, (3)腫瘍陰影の硬さが少いことなどをあげてい るが, 自験例では, むしろ小腸癌に特徵的な overhang-

図 6 腫晹の存在部位

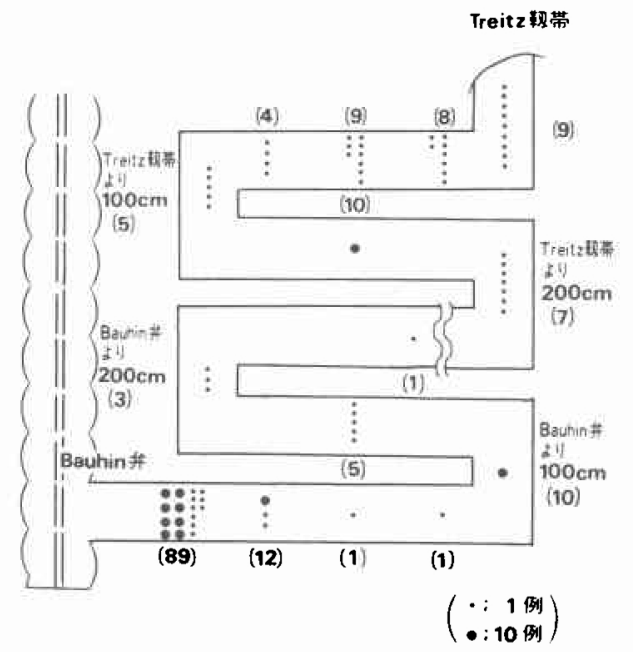

表 4 臨休症状

\begin{tabular}{|c|c|c|}
\hline 症 状 & 例数 & $\%$ \\
\hline & 149 & $(58.9)$ \\
\hline 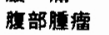 & 73 & $(28.9)$ \\
\hline 吐 & 41 & $(16.2)$ \\
\hline 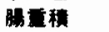 & 37 & $(14.6)$ \\
\hline イレゥス & 34 & (13.4) \\
\hline 消化管出血 & 34 & $(13.4)$ \\
\hline 脚部膨满 & 27 & $(10.7)$ \\
\hline 発 笴 & 18 & $(7.1)$ \\
\hline 下疬 & 18 & (7.1) \\
\hline 弗の他 & 115 & $(45.4)$ \\
\hline
\end{tabular}


ing edgeがみられ，両者の鑑別が困難であった。

血管造影上の特徵としては，hypovascularity ${ }^{8) か ゙ あ ~}$ げられ，自験例でもそれ以外に特徴的所見を認めな かった。

悪性リンパ腫の化学療法については, 数多くの報告 があるが, 木村らは99, Vincristine, Bleomycin, Cyclophosphamide, Prednisolone の 4 昘併用療法を行って 良好な成績を納めている。自験例では, Bleomycinを 肺毒性の少いPepleomycin に変更して 4 剂併用療法, すなわち COPP 㞠法を術後 4 クール行い, 全く副作用 を認めず，患者は正常の日常生活を行っている。

本疾患の予後について, 諸家の 5 年生存率は, $13.2 \%^{2)}, 0 \%$, $33.6 \%^{10)}$ であった。米国では, Naqvi らは33.3\% ${ }^{111}$ と報告しているが，いずれる予後良好と はいえず，今後の診断治療の進歩が望まれる。

$$
\text { まとめ }
$$

われわれは, 原発性空腸悪性リンパ腫の 1 例を経験 したので，若干の文献的考察を加えて報告した。 本文の要旨は第59回中国四国外科学会において発表し た。

\section{文献}

1）田中啓二：切除された空・回腸尰瘍20例の X 線学 的検討. 胃と腸 $16: 971-989 ， 1981$

2）森茂郎, 山口和克, 喜納 勇ほか: 腸原発悪性リ ンパ庫の病理. 癌の臨 $20: 481-489,1974$
3）森 茂郎：病理組織学的分類の現況. 内科 48： $9-13,1981$

4）八尾佰良, 日吉雄一, 田中啓二注か：最近10年間 （1970－1979）の本邦報告例の集計からみた空・回 腸腫場。胃之腸 $16: 935-941 ， 1981$

5）高橋日出雄, 東郷実元, 穴沢貞夫ほか：小腸非上皮 性腫瘍の臨床病理学的検討. 外科診療 22 : $855-859,1980$

6）高見元敬, 木村正治,花田正人ほか：小腸腫湯の臨 床病状と発見へのアプローチ。胃と腸 16 ： 959-969, 1981

7）大垣移久, 稲本 俊, 仁尾義則注か：小腸腫㩧。消 外 $5: 932-936,1982$

8）小林一雄, 森 克彦, 永沢康滋注か：小腸疾患に打 ける血管造影の経験. 日消外会誌 $16: 576-582$, 1983

9）木村郁郎, 大晹泰亮，中田安成ほか：覀性リンパ腫 治療における Vincristine, Bleomycin, Cyclophosphamide および prednisolone4剤併用療法. 長期観察で得られた成績について. 臨血 21： $792-800,1980$

10）中村敬夫：胃腸管覀性リンパ腫の臨床病理学的並 びに免疫組織学的検討. 日消病会誌 79： 2216-2226, 1982

11) Naqvi MS, Burrows L, Kark AE: Lymphoma of the gastrointestinal tract: prognostic guides based on 162 Cases. Ann Surg $170: 221-231$, 1969 